\title{
Spectroscopic and Substitution Kinetic Studies of Hexacyanoferrate(II) Complexes by EDTA Catalysed with Mercury(II)
}

\author{
K.S. SIDDIQI*, AFTAB ASLAM PARWAZ KHAN, \\ AYAZ MOHD and SHAISTA BANO \\ Department of Chemistry, \\ Aligarh Muslim University, Aligarh- 20200, (U.P.), India. \\ ks_siddiqi@yahoo.co.in
}

Received 3 March 2009; Accepted 1 May 2009

\begin{abstract}
Kinetics and mechanism of substitution of cyanide ion in hexacyanoferrate(II) by EDTA catalysed by mercury(II) has been studied spectrophotometrically at $365 \mathrm{~nm}$ in potassium hydrogen phthalate buffer of $\mathrm{pH}$ $=5.0$ and ionic strength, $\mathrm{I}=0.1 \mathrm{M}$, maintained by $\left(\mathrm{KNO}_{3}\right)$ at $25{ }^{\circ} \mathrm{C}$. Effect of the $\mathrm{pH}$ and concentration of the EDTA, $\left[\mathrm{Fe}(\mathrm{CN})^{4-}{ }_{6}\right]$ on the rate of reaction has been studied. The kinetics and mechanism of the reaction has been shown through dissociative mechanism. The mechanism of ligand substitution in the complex together with the kinetic data has been shown. The catalytic activity of mercury(II) has also been studied as a function of its concentration. The maximum reaction product was detected at $\mathrm{pH}=5$ after which a decline in absorption occurs followed by precipitation. It is an inexpensive method to identify and remove the cyanide ion in solution even in very low concentration of the order of $10^{-4} \mathrm{M}$.
\end{abstract}

Keyword: Kinetics, Hexacyanoferrate(II), EDTA, Mercury(II), Thermodynamics, Mechanism.

\section{Introduction}

It has been demonstrated that of all the heavy metals mercury(II) easily forms bonds to cyanide and slowly removes it from hexacyanoferrate(II). Kinetics and mechanism of ligand replacement in low spin $\mathrm{Fe}$ (II) complex has been done, although it is limited to the study of pentacyano(L)ferrate(II) complex ${ }^{1-7}$. Few studies have been done in aqueous electrolyte and micellar media to acquire an in depth knowledge of the mechanistic scheme ${ }^{8-9}$. The oxidation kinetics of the hexacyanoferrate(II) complex by various reagents in acidic and basic media have been studied and all these investigation have been applied to specific analytical problems ${ }^{10-12} . \mathrm{K}_{4}\left[\mathrm{Fe}(\mathrm{CN})_{6}^{4-}\right]$ hardly undergoes exchange reaction as $\mathrm{CN}^{-}$itself is a 
very strong ligand although slow exchange of labelled $\mathrm{CN}^{-}$group or aminopyridine has been demonstrated. Under UV light reversible aquation occurs leading to the formation ${ }^{13}$ of $\left[\mathrm{Fe}(\mathrm{CN})_{5} \mathrm{H}_{2} \mathrm{O}\right]^{3-}$. However, only mono substituted $\left[\mathrm{Fe}(\mathrm{CN})_{5} \mathrm{~L}\right]^{3-}$ have been obtained either through photochemical or by dissociation reaction or by metal catalysed substitution reaction ${ }^{14}$.

$$
\left[\mathrm{Fe}(\mathrm{CN})_{6}{ }^{4-}\right]+\mathrm{H}_{2} \mathrm{O} \longrightarrow\left[\mathrm{Fe}(\mathrm{CN})_{5} \mathrm{H}_{2} \mathrm{O}\right]^{3-}+\mathrm{CN}^{-}
$$

Hexacyanoferrate(II) reacts with EDTA according to the following equation

$$
\begin{aligned}
{\left[\mathrm{Fe}(\mathrm{CN})_{5} \mathrm{H}_{2} \mathrm{O}\right]^{3-}+\mathrm{EDTA} } & \longrightarrow\left[\mathrm{Fe}(\mathrm{CN})_{5} \mathrm{EDTA}\right]^{3-}+\mathrm{H}_{2} \mathrm{O} \\
\mathrm{CN}^{-}+\mathrm{H}_{2} \mathrm{O} & \longrightarrow \mathrm{HCN}+\mathrm{OH}^{-}
\end{aligned}
$$

Mercury(II) readily forms complex with cyanide ion but decomposition occurs in UV light.

$$
\begin{aligned}
\mathrm{Hg}^{2+}+\left[\mathrm{Fe}(\mathrm{CN})_{6}{ }^{4-}\right]+\mathrm{H}_{2} \mathrm{O} & \longrightarrow\left[\mathrm{Fe}(\mathrm{CN})_{5} \mathrm{H}_{2} \mathrm{O}\right]^{3-}+\mathrm{HgCN}^{+} \\
\mathrm{HgCN}^{+} \mathrm{H}^{+} & \longrightarrow \mathrm{HCN}+\mathrm{Hg}^{2+}
\end{aligned}
$$

In the present work, we have studied the kinetics of substitution of $\mathrm{CN}^{-}$by EDTA, catalysed by $\mathrm{Hg}^{2+}$ A probable mechanism of the reaction has been proposed. Any attempt to study the substitution of $\mathrm{CN}^{-}$by phenanthroline, pyridine, hydrazine and piperazine resulted in precipitation even in low concentration.

\section{Experimental}

Double distilled, de-ionized water was used throughout. The chemicals used were of analytical grade. Stock solutions of the compounds were wrapped with carbon paper to protect them from photodecomposition. The mercury(II) and hexacyanoferrate(II) solutions were diluted just before use. The desired $\mathrm{pH}=5$ of the reaction mixture was maintained by adding $\mathrm{KHP}-\mathrm{NaOH}$ buffer $^{15}$. The ionic strength was maintained at $0.1 \mathrm{M}$ by adding appropriate amount of $\mathrm{KNO}_{3}$.

\section{Apparatus}

The absorption spectra were obtained with double beam UV-vis spectrophotometer (ElicoSL-169). pH-metric measurements were done with Elico-LI $120 \mathrm{pH}$ meter.

\section{Procedure}

All the solutions were thermally equilibrated for about 30 minutes at $25{ }^{\circ} \mathrm{C}$ and $2.0 \mathrm{~mL}$ of each EDTA, phthalate buffer of $\mathrm{pH}=5.0$ and mercury(II) chloride were mixed in a flask and left for $10 \mathrm{~min}$ to ensure complete reaction. Finally, $2.0 \mathrm{~mL}$ of $\left[\mathrm{Fe}(\mathrm{CN})_{6}\right]^{4-}$ was added to this mixture and the wavelength of maximum absorption $(365 \mathrm{~nm})$ was determined (Figure 1).

\section{Effect of $p H$}

The reaction was studied first by fixed time kinetic method in the $\mathrm{pH}$ ranges 1-13. Figure 2 shows plots of absorbance (measured at $\mathrm{t}=5$ and 10 minutes after mixing the reagents) versus $\mathrm{pH}$ of the reaction mixture. It was found that, with increasing $\mathrm{pH}$ the absorbance increases and attains a maximum between $\mathrm{pH} 5.0$ to 5.5. However, above this $\mathrm{pH}$ the absorption decreases which is due to the deficiency of protons. The rate is reduced at low $\mathrm{pH}$ value due to the formation of various protonated forms of $\left[\mathrm{Fe}(\mathrm{CN})_{6}\right]^{4-}$ which are less reactive than $\left[\mathrm{Fe}(\mathrm{CN})_{6}{ }^{4-}\right]$ itself $^{16}$.

\section{Effect of EDTA}

The complex formation with EDTA is influenced by a change in the $\mathrm{pH}$ of solution which is perhaps due to ionization of the metal complex at low $\mathrm{pH}$ and hydrolysis of the metal ion at higher $\mathrm{pH}$. The effect of EDTA was examined as a function of its concentration at a fixed 
$\mathrm{pH}$ 5. A plot of initial rate versus EDTA is shown in Figure 3. Almost constant rate was obtained in the concentration range $2 \times 10^{-5}$ to $7 \times 10^{-5} \mathrm{M}$ and finally decrease at still higher concentrations. A fixed concentration $4 \times 10^{-4} \mathrm{M}$ was thus selected as optimum.

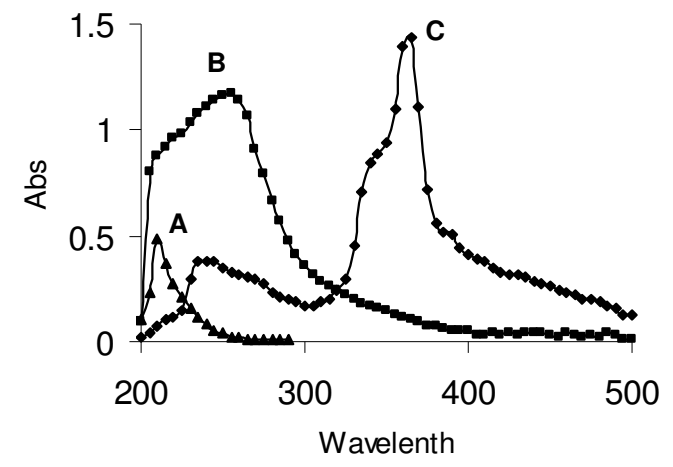

Figure 1. Absorption spectra of reactants and products: $(\mathrm{A})[\mathrm{EDTA}]=1 \times 10^{-3} ;(\mathrm{B})\left[\mathrm{Fe}(\mathrm{CN})_{6}\right]^{4-}$ $=5 \times 10^{-4} \mathrm{M}(\mathrm{C})\left[\mathrm{Fe}(\mathrm{CN})_{6}\right]^{4}=4 \times 10^{-4} \mathrm{M},[$ EDTA $]=4 \times 10^{-3} \mathrm{M},\left[\mathrm{Hg}^{2+}\right]=3 \times 10^{-5} \mathrm{M}$ and $\mathrm{pH}=5.0$

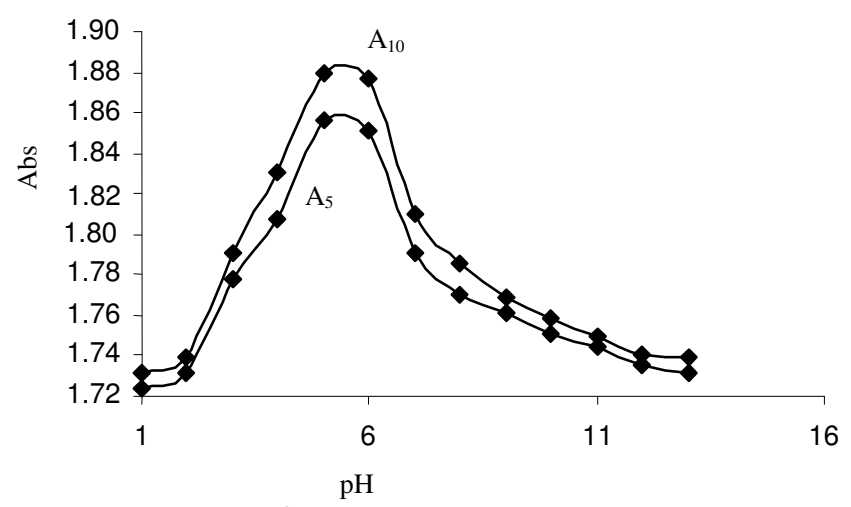

Figure 2. Effect of $\mathrm{pH}$ on $\mathrm{Hg}^{2+}$ catalysed substitution of $\mathrm{CN}^{-}$in hexacyanoferrate(II) by EDTA ion at $\left[\mathrm{Fe}(\mathrm{CN})_{6}^{4-}\right]=5 \times 10^{-3} \mathrm{M}$, EDTA $=5 \times 10^{-5} \mathrm{M},\left[\mathrm{Hg}^{2+}\right]=3 \times 10^{-5} \mathrm{M}$, Temp $=25{ }^{0} \mathrm{C}$ and $\mathrm{I}=0.1 \mathrm{M}\left(\mathrm{KNO}_{3}\right)$.

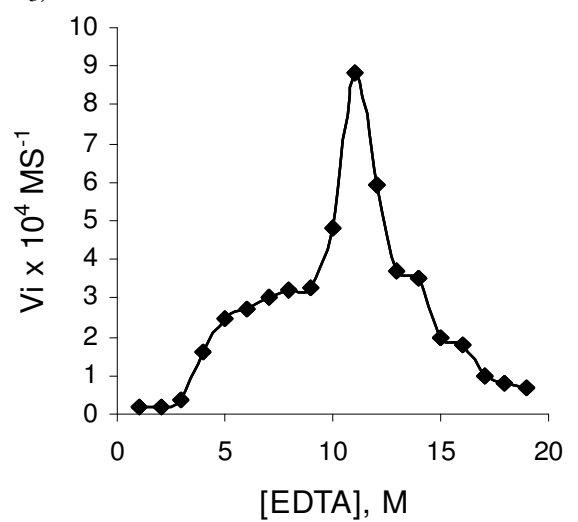

Figure 3. Effect of EDTA on initial rate at $\left[\mathrm{Fe}(\mathrm{CN})_{6}{ }^{4-}\right]=3.5 \times 10^{-2} \mathrm{M},\left[\mathrm{Hg}^{2+}\right]=3 \times 10^{-5} \mathrm{M}$, $\mathrm{pH}=5$, Temp $=25{ }^{\circ} \mathrm{C}$ and $\mathrm{I}=0.1 \mathrm{M}\left(\mathrm{KNO}_{3}\right)$ 


\section{Effect of $\left[\mathrm{Fe}(\mathrm{CN})_{6}\right]^{4-}$ on the initial rate}

Dependence in $\left[\mathrm{Fe}(\mathrm{CN})_{6}^{4-}\right]$ was found, changing from first order at lower concentration to higher concentration not zeroth order, Keeping all parameters constant, effect of the concentration of $\left[\mathrm{Fe}(\mathrm{CN})_{6}{ }^{4-}\right]$ on the reaction rate was studied in the concentration range $5 \times 10^{-4}$ to $2 \times 10^{-2} \mathrm{M}$, Figure 4 .A variable order .

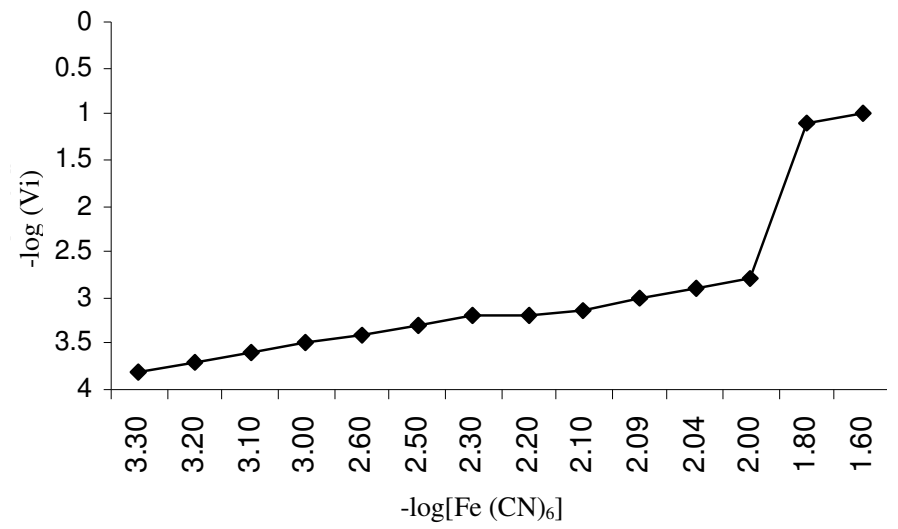

Figure 4. Dependence of the initial rate on $\left[\mathrm{Fe}(\mathrm{CN})_{6}^{4-}\right]$ in presence of $\left[\mathrm{Hg}^{2+}\right]$ at [EDTA] $3 \times 10^{-4} \mathrm{M},\left[\mathrm{Hg}^{2+}\right]=3 \times 10^{-5} \mathrm{M}, \mathrm{pH} 5.0$, temp $=25{ }^{0} \mathrm{C}$ and $0.2 \mathrm{M}\left(\mathrm{KNO}_{3}\right)$.

\section{Effect of $\left[\mathrm{Hg}^{2+}\right]$ on initial rate}

The concentration of mercury(II) was kept between $1 \times 10^{-5}$ to $2 \times 10^{-3} \mathrm{M}$ and those of the $\left[\mathrm{Fe}(\mathrm{CN})_{6}{ }^{4-}\right]$ and EDTA were kept constant. The $\mathrm{pH}$ and temperature were maintained at 5 and $25{ }^{\circ} \mathrm{C}$ respectively. The results are shown in Figure 5. The large variation in $\left[\mathrm{Hg}^{2+}\right]$ was selected in order to test the linearity between initial rate and $\left[\mathrm{Hg}^{2+}\right]$ for its analytical application and also the changing role in $\left[\mathrm{Hg}^{2+}\right]$ mixture. A plot of the absorbance measured after an interval of one min versus $\left[\mathrm{Hg}^{2+}\right]$ as a function of $\mathrm{pH}$ is given in Figure 5.

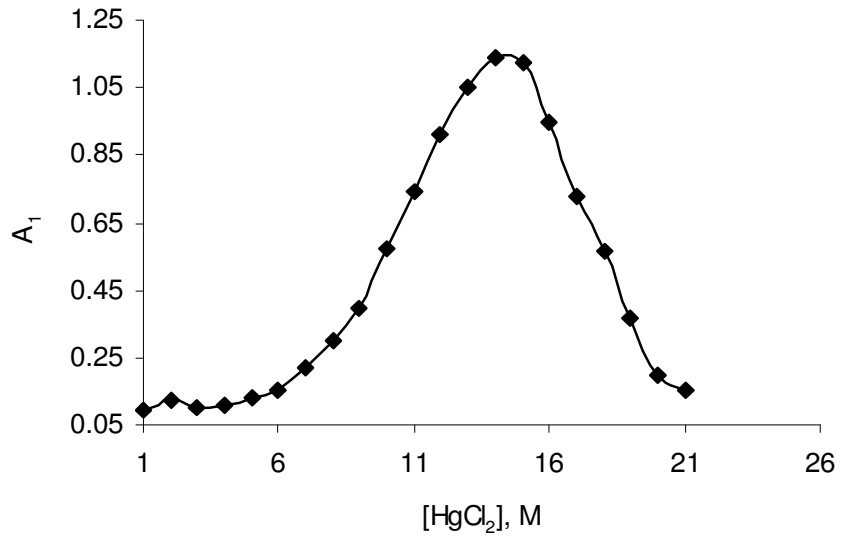

Figure 5. Dependence of the initial rate of substitution of $\mathrm{CN}^{-}$in $\left[\mathrm{Fe}(\mathrm{CN})_{6}{ }^{4-}\right]$ by EDTA on $\left[\mathrm{HgCl}_{2}\right]$ at $\left[\mathrm{Fe}(\mathrm{CN})_{6}{ }^{4-}\right]=3.5 \times 10^{-3} \mathrm{M},[\mathrm{EDTA}]=3 \times 10^{-4} \mathrm{M}, \mathrm{pH}=5$, temp $=25^{\circ} \mathrm{C}$ and $\mathrm{I}=$ $0.1 \mathrm{M}\left(\mathrm{KNO}_{3}\right)$.

It clearly indicates that the rate increases linearly until the ratio of the $\left[\mathrm{Fe}(\mathrm{CN})_{6}{ }^{4}\right]$ and $\left[\mathrm{Hg}^{2+}\right]$ reaches 1:1. When the concentration of $\left[\mathrm{Hg}^{2+}\right]$ exceeds that of $\left[\mathrm{Fe}(\mathrm{CN})_{6}{ }^{4}\right]$ the absorption begins to 
decrease and follows a non-linear pattern. The intercept computed from the initial linear portion of the Figure 5 provides the rate due to the uncatalyzed path. However, decline in the rate of reaction at higher $\left[\mathrm{Hg}^{2+}\right]$ is probably due to the formation of a binary adduct, $\left[\mathrm{Fe}(\mathrm{CN})_{6}^{4-} \cdot \mathrm{HgCl}_{2}\right]$. In a separate experiment it was observed that a white precipitate is formed immediately after mixing $\left[\mathrm{Fe}(\mathrm{CN})_{6}{ }^{4-}\right]$ with $\left[\mathrm{Hg}^{2+}\right]$ in $1: 2$ molar ratio which rapidly turned blue, confirming the formation of a binuclear complex. A similar observation has also been made by Beck $^{17}$.

\section{Effect of temperature and ionic strength}

The rate of the $\left[\mathrm{Hg}^{2+}\right]$ catalyzed ligand exchange between $\left[\mathrm{Fe}(\mathrm{CN})_{6}^{4-}\right]$ and EDTA was studied as a function of temperature in range $20-30{ }^{0} \mathrm{C}$. The higher temperature was avoided due to the possibility of decomposition of $\left[\mathrm{Fe}(\mathrm{CN})_{5} \mathrm{EDTA}\right]^{3-}$. The Arrhenius equation was used to determine the activation energy (Ea) for the catalyzed reaction and the other activation parameters, viz. enthalpy of activation $\left(\Delta \mathrm{H}^{\ddagger}\right)$ and entropy of activation $\left(\Delta \mathrm{S}^{\ddagger}\right)$ were calculated using Eyring equation. The values of activation parameters are found to be $\mathrm{Ea}=78.2 \mathrm{~kJ} \mathrm{~mol}^{-1}, \Delta \mathrm{S}^{\neq}=-48.67 \mathrm{JK}^{-1} \mathrm{~mole}^{-1}$ and $\Delta \mathrm{H}^{\neq}=-52.5 \mathrm{~kJ} \mathrm{~mole}^{-1}$. The effect of ionic strength on the initial rate of reaction was also studied employing $\left(\mathrm{KNO}_{3}\right)$ for maintaining ionic strength in the 0.015 to $0.2 \mathrm{M}$ range. The higher ionic strength was avoided due to the limited solubility of $\left(\mathrm{KNO}_{3}\right)$. When $\mathrm{KCl}$ was used to maintain the ionic strength the rate was found to decrease considerably. This is probably due to a subsequent decrease in $\left[\mathrm{Hg}^{2+}\right]$ or $\left[\mathrm{HgCl}^{+}\right]$along with the concentration of an ion-pair formation between $\left[\mathrm{Fe}(\mathrm{CN})_{6}^{4-}\right]$ and $\left[\mathrm{Hg}^{2+}\right]^{18}$.

\section{Results and Discussion}

The following Scheme for the mercury(II) catalyzed ligand exchange between $\left[\mathrm{Fe}(\mathrm{CN})_{6}{ }^{4-}\right]$ and EDTA has been proposed:

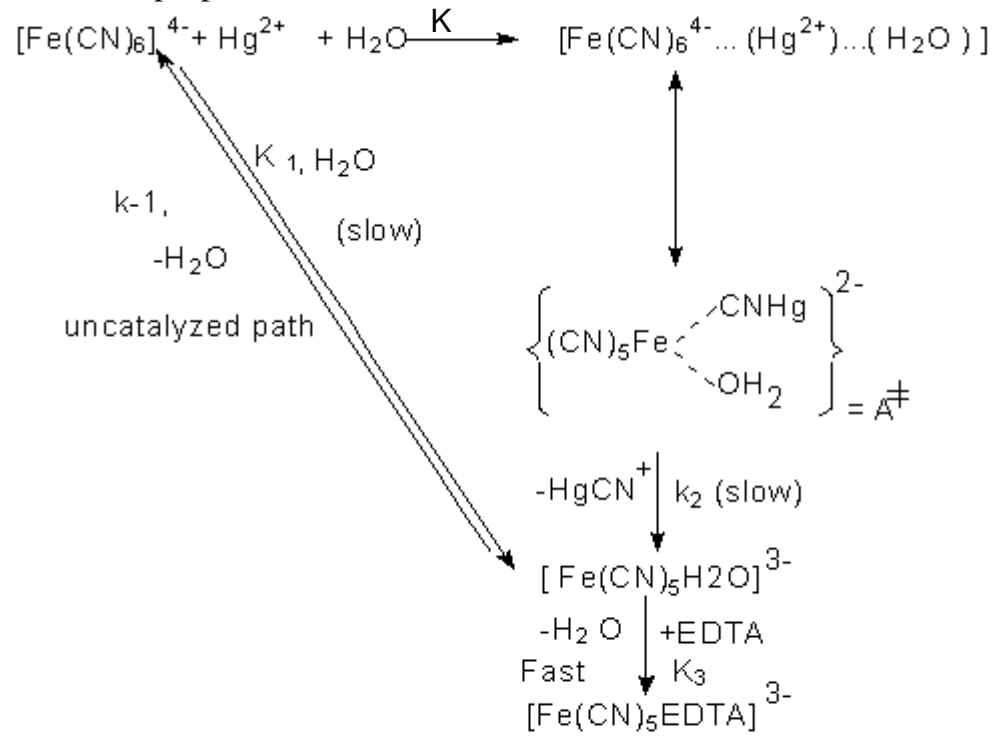

$$
\mathrm{HgCN}^{+}+\mathrm{H}^{+} \longrightarrow \mathrm{Hg}^{2+}+\mathrm{HCN}
$$


Formation of the complex, $\left[\mathrm{Fe}(\mathrm{CN})_{5} \mathrm{EDTA}\right]^{3-}$ through the catalyzed path can be written as:

$$
\frac{\mathrm{d}\left[\mathrm{Fe}(\mathrm{CN})_{5} \mathrm{EDTA}^{3-}\right.}{\mathrm{dt}}=\mathrm{K}_{2}\left[\mathrm{~A}^{\neq}\right]
$$

While, that for the uncatalyzed path the

$$
\text { rate }=\mathrm{k}^{\prime}\left[\mathrm{Fe}(\mathrm{CN})_{6}^{4-}\right]
$$

where, $\mathrm{k}^{\prime}$ is a composite rate constant involving a concentration term. If the rate determining step is taken to be the composition of the activated complex $\left(\mathrm{A}^{\neq}\right)$, the activity of the mercury(II) at low concentration can be easily explained by the above mechanism. The overall rate for uncatalyzed reaction can be expressed through equation (13) using a non limiting concentration of EDTA.

$$
\text { Rate }=\frac{\mathrm{d}\left[\mathrm{Fe}(\mathrm{CN})_{5} \mathrm{EDTA}^{3-}\right.}{\mathrm{dt}}=\mathrm{k}^{\prime}\left[\mathrm{Fe}(\mathrm{CN})_{6}{ }^{4-}\right]+\frac{\mathrm{k}_{2} \mathrm{~K}\left[\mathrm{Fe}(\mathrm{CN})_{6}{ }^{4-}\right]\left[\mathrm{Hg}^{2+}\right]\left[\mathrm{H}_{2} \mathrm{O}\right]}{1+\mathrm{K}\left[\mathrm{Fe}(\mathrm{CN})_{6}{ }^{4-}\right]}
$$

The second term in the above equation refers to the rate of the catalyzed reaction and explains the variable order dependence in $\left[\mathrm{Fe}(\mathrm{CN})_{6}{ }^{4-}\right] . \mathrm{K}$ is defined as the equilibrium constant for the association of the mercury (II) with water and $\left[\mathrm{Fe}(\mathrm{CN})_{6}{ }^{4-}\right]$. Since water is in a large excess, the equation (14) is reduced to equation (15)

$$
\text { Rate }=\mathrm{k}^{\prime}\left[\mathrm{Fe}(\mathrm{CN})_{6}{ }^{4-}\right]+\mathrm{k}_{2}{ }_{2} \mathrm{~K}\left[\mathrm{Hg}^{2+}\right]\left[\mathrm{Fe}(\mathrm{CN})_{6}{ }^{4-}\right]
$$

Now equation (15) yields the observed rate constant $\left(\mathrm{k}_{\mathrm{obs}}\right)$ as expressed by equation (16)

where, $\mathrm{k}_{2}^{\prime}=\mathrm{k}_{2}+\left[\mathrm{H}_{2} \mathrm{O}\right]$.

$$
\mathrm{k}_{\mathrm{obs}}=\mathrm{k}^{\prime}+\mathrm{k}_{2}^{\prime} \mathrm{K}\left[\mathrm{Hg}^{2+}\right]
$$

A plot of the initial rate versus $\left[\mathrm{Hg}^{2+}\right]$ at low $\left[\mathrm{Fe}(\mathrm{CN})_{6}{ }^{4-}\right]$ is given in Figure 6. In case of higher $\left[\mathrm{Fe}(\mathrm{CN})_{6}^{4-}\right]$, equation (14) takes the form of equation (17).



Figure 6. $\left[\mathrm{Fe}(\mathrm{CN})_{6}{ }^{4-}\right]=8 \times 10^{-4} \mathrm{M},[\mathrm{EDTA}]=5 \times 10^{-4} \mathrm{M}, \mathrm{pH}=5$, temp. $=25^{0} \mathrm{C}, \mathrm{I}=0.1 \mathrm{M}\left(\mathrm{KNO}_{3}\right)$.

The value of the initial rate $\left(\mathrm{V}_{\mathrm{i}}\right)$ as a function of $\left[\mathrm{Hg}^{2+}\right]$ at low $\left[\mathrm{Fe}(\mathrm{CN})_{6}^{4-}\right]$ is listed in Table 1. The value of the $\mathrm{k}^{\prime}$ and $\mathrm{k}_{2}$ ' have been calculated from the plot Figure 6 of initial rate versus $\left[\mathrm{Hg}^{2+}\right]$ using equation (17) at specified experimental condition. The rate constant $\mathrm{k}^{\prime}$ and $\mathrm{k}_{2}$ are found to be $4.17 \times 10^{-3} \mathrm{~s}^{-1}$ and $2.50 \mathrm{~s}^{-1}$ respectively, at $\mathrm{I}=0.1 \mathrm{M}, \mathrm{pH}=5$, temp $=2{ }^{0} \mathrm{C}$ .The value of $\mathrm{k}_{1}{ }^{\prime}$ and $\mathrm{k}_{2}$ so obtained are substituted in equation (17) to evaluate the equilibrium constant $\mathrm{K}$ at various $\left[\mathrm{Hg}^{2+}\right]$ at low $\left[\mathrm{Fe}(\mathrm{CN})_{6}^{4-}\right]$. The $\mathrm{K}$ (Table 1) and the average value of $\log \mathrm{K}(2.80)$ in our case is comparable with that reported by Beck for $\left[\mathrm{Fe}(\mathrm{CN})_{6}{ }_{6}^{4-} \cdot \mathrm{Hg}(\mathrm{CN})_{2}\right]$ complex $(\operatorname{logK}=2.38)^{17}$. Although the values of $\mathrm{k}_{2}$ have been calculated employing high $\left[\mathrm{Fe}(\mathrm{CN})_{6}{ }^{4-}\right]$ using equation $(17)$ it can be obtained even at low $\left[\mathrm{Fe}(\mathrm{CN})_{6}{ }^{4-}\right]$ using equation (18) 
Table 1. Calculation of $\mathrm{K}$ by varying $\left[\mathrm{Hg}^{2+}\right]$ at constant $\left[\mathrm{Fe}(\mathrm{CN})_{6}{ }^{4-}\right] .\left[\mathrm{Fe}(\mathrm{CN})_{6}{ }^{4-}\right]=8 \times 10^{-4} \mathrm{M}$, $\left[\mathrm{Hg}^{2+}\right]=5 \times 10^{4-} \mathrm{M}, \mathrm{pH}=5$, temp $=25^{\circ} \mathrm{C}$ and $\mathrm{I}=0.1 \mathrm{M}\left(\mathrm{KNO}_{3}\right)$,

\begin{tabular}{|c|c|c|}
\hline$\left[\mathrm{Hg}^{2+}\right] \times 10^{-4}, \mathrm{M}$ & Vi $\times 10^{4}$ & $\mathrm{~K}$ (calcd.) \\
\hline 2 & 3.5 & 709.07 \\
\hline 4 & 5.9 & 660.02 \\
\hline 6 & 7.9 & 610.60 \\
\hline 8 & 10.6 & 625.80 \\
\hline 10 & 12.6 & 601.80 \\
\hline \multicolumn{3}{|c|}{ Average $\log K=2.80$} \\
\hline
\end{tabular}

However, the values calculated from this equation are almost identical. The ionic behavior of $\left[\mathrm{Hg}^{2+}\right]$ may be represented by the following reactions.

$$
\begin{aligned}
& \mathrm{Hg}^{2+}+\mathrm{Ci} \rightleftharpoons \mathrm{k}_{1} \mathrm{HgCl}^{+}
\end{aligned}
$$

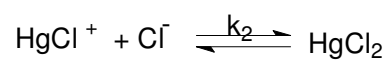

It has been shown that when $\mathrm{Hg}\left(\mathrm{NO}_{3}\right)_{2}$ reacts with $\left[\mathrm{Fe}(\mathrm{CN})_{6}{ }^{4-}\right]$ in solution the resultant was $\mathrm{Hg}_{2}\left[\mathrm{Fe}(\mathrm{CN})_{6}{ }^{4-}\right]^{19}$, which has also been verified from the absorption spectra of both the reacting components and the eventual product. This is quite obvious because the $\left[\mathrm{Hg}^{2+}\right]$ is more electropositive than $\mathrm{K}^{+}$ion. The activation energy calculated for this reaction is a little less than the reported values in the literature ${ }^{20,21}$ for the replacement of $\mathrm{CN}^{-}$in nearly similar reaction systems. The entropy of activation is negative and is expected if the virtual solvations of the activated complex and its highly charged dissociation products are considered. Thus, the activation parameters provide further support to the proposed mechanism.

\section{Conclusion}

In the present work we have studied the kinetics of substitution of $\mathrm{CN}^{-}$by EDTA catalyzed with $\left[\mathrm{Hg}^{2+}\right]$. A probable mechanism of the reaction has been proposed. The results presented here clearly demonstrate work, EDTA as a chelating agent was used for the neutralization of $\mathrm{CN}^{-}$in complex formation which is more effective and inexpensive. The values of thermodynamic parameters for complex formation are found to be $\mathrm{Ea}=78.2 \mathrm{~kJ} \mathrm{~mol}^{-1}, \Delta \mathrm{S}^{\neq}=$ $-48.67 \mathrm{JK}^{-1} \mathrm{~mole}^{-1}$ and $\Delta \mathrm{H}^{\neq}=-52.5 \mathrm{~kJ}$ mole ${ }^{-1}$. The negative value of shows the exothermic nature of reaction.

\section{References}

1. Abu-Gharib E A, Ali R, Blandamer M J, Burgess J, Transition Met Chem., 1987, 12, 371 .

2. Stochel G, van Eldik R, Inorg Chim Acta, 1989, 155, 95.

3. Borges S D S S, Coelho A L, Moreira I S and Araujo M A B D, Polyhedron, 1994, 13, 1015

4. $\quad$ Alshehri S, Transition Met Chem., 1997, 22, 553.

5. Maciejowska I, Stasicka Z, Stochel G and van Eldik R, J Chem Soc., 1999, 3643. 
6. Fernandez G, Del M G M, Rodriguz A, Munoz M, Moya M L, React Kinet Cat Lett., $2000,70,389$.

7. Sabo E M, Shepherd R E, Rau M S and Elliott M G, Inorg Chem., 1987, 26, 2897.

8. Fernando M D, Refael J, Carlos G H and Francisco S, New J Chem., 1999, 23, 1203.

9 Fernandez G, Del M G M, Rodriguz A, Munoz M and Moya M L, J Colloid Interface Sci., 2000, 225, 47.

10. He R and Wang J, Xiуou Jinshu Cailiao Yu Gongcheng, 1999, 28, 60; Chem Abstr., 1999, 130, 275849g.

11. Zmikic A, Cvrtila D, Pavlovic D, Murati I, Reynolds W and Asperger S, J Chem Soc., Dalton Trans., 1973, 1284.

12. Feng Y L, Narasaki H, Tian L C, Wu S M and Chen H.Y, Anal Sci., 1999, 15, 915.

13. Alam T and Kamaluddin, Bull Chem Soc Jpn., 1999, 72, 1697.

14. Sharpe A G, The Chemistry of Cyano Complexes of Transition Metals, Academic Press, London, 1976, p. 1081, 1262.

15. Weast R C, CRC Handbook of Chemistry and Physics, The Chemical Rubber Co., Ohio, $49^{\text {th }}$ Ed., 1969, D-79

16 Eaton W A, George P and Hanaria G H, J Phys Chem., 1967, 71, 2016.

17. Beck M T, Fourteen: A Magic Number of Coordination Chemistry, Proc. XX ICCC, Calcutta, India, 1979, In Coordination Chemistry-20, Pergamon Press, Oxford, 1979, p. 31.

18. Masaru Kimura, Yuko Shiota, Shinobu Kishi and Keiichi Tsukahara, Bull Chem Soc., 1999, 72, 1293-1299

19 Athos Bellomo, Domenico De Marco and Agatino Casale, Talanta, 1975, 22, 197-199

20. Reddy B R and Raman S, Indian J Chem., 1984, 23A, 616.

21. Raman S, Indian J Chem., 1980, 19, 907. 


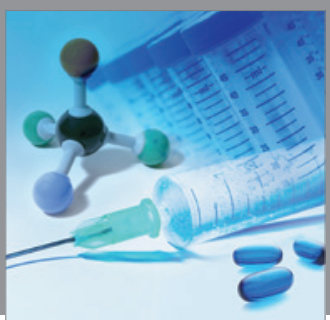

International Journal of

Medicinal Chemistry

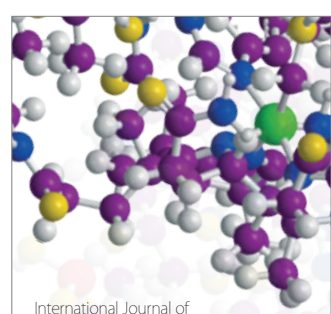

Carbohydrate Chemistry

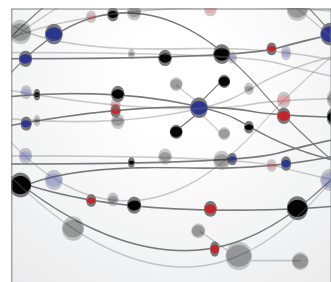

The Scientific World Journal
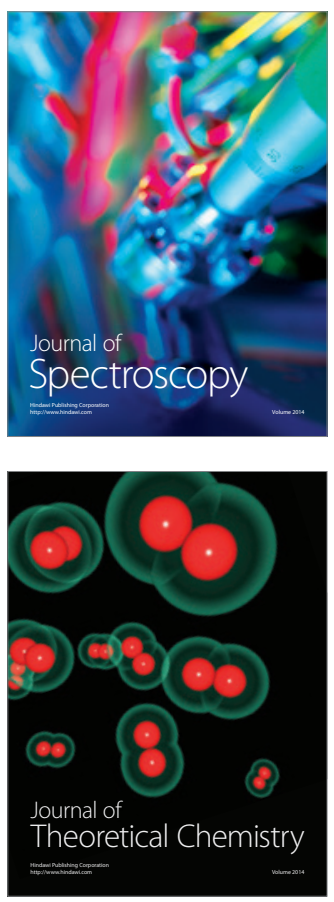
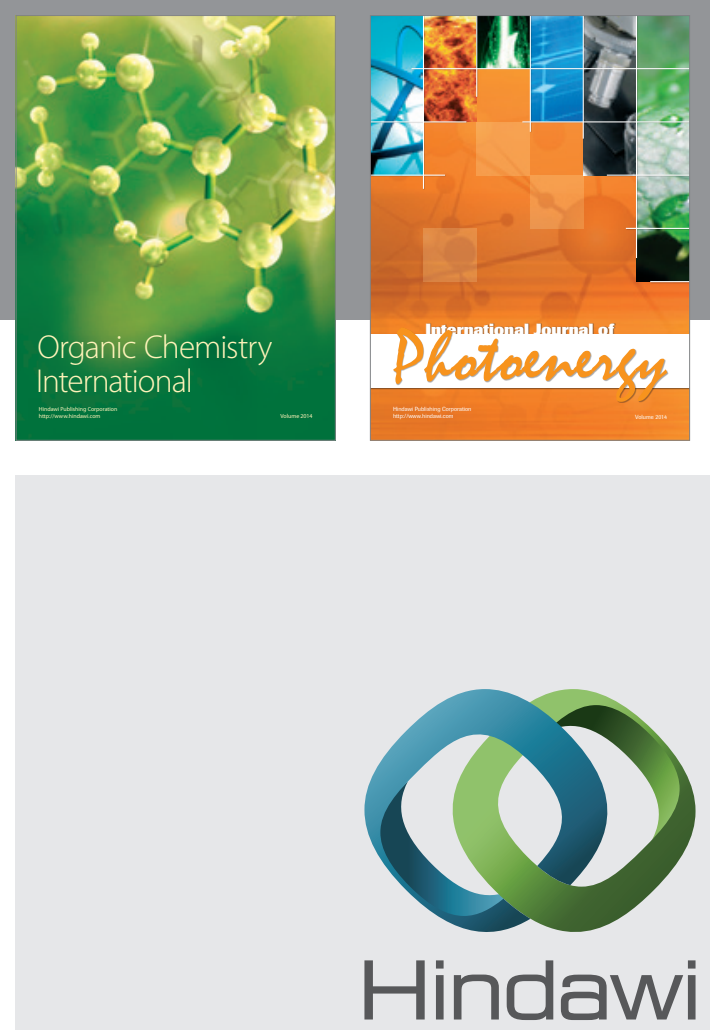

Submit your manuscripts at

http://www.hindawi.com
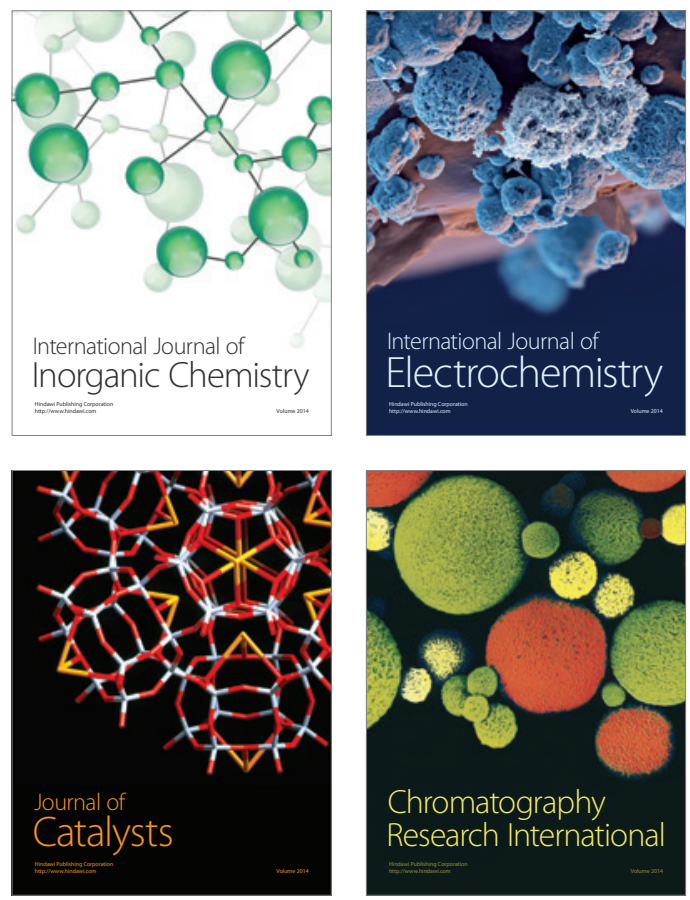
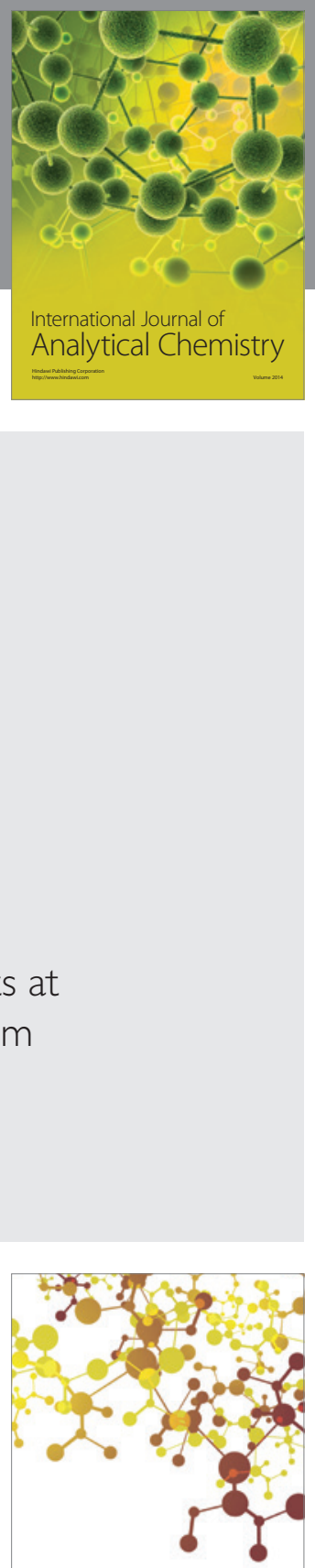

Journal of

Applied Chemistry
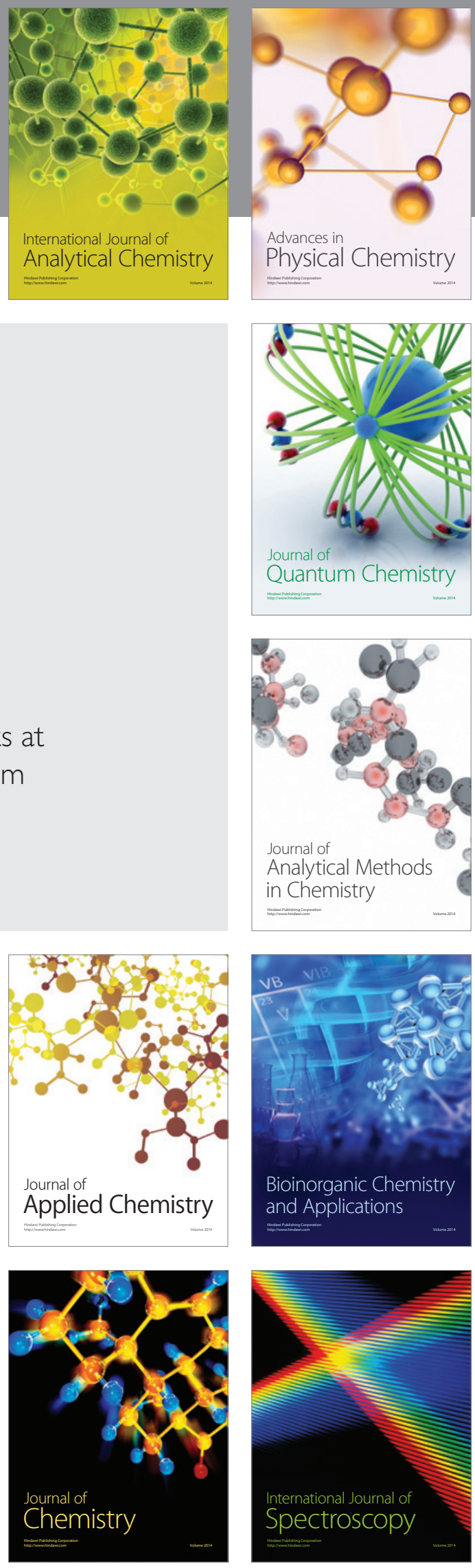